\title{
ANALISIS KAPASITAS JALAN MENGGUNAKAN PENDEKATAN GEOSPASIAL (WILAYAH STUDI: BANDUNG TENGAH)
}

\author{
Irwan Susanto ${ }^{1}$, Moch.Duddy Studyana², Yackob Astor ${ }^{2}$ \\ ${ }^{1}$ Mahasiswa DIV-Teknik Perancangan Jalan dan Jembatan Jurusan Teknik Sipil Politeknik Negeri \\ Bandung Jl. Gegerkalong Hilir Ds. Ciwaruga Bandung 40012. Email: irwan.civileng@ gmail.com \\ ${ }^{2}$ Staf pengajar Jurusan Teknik Sipil Politeknik Negeri Bandung Jl. Gegerkalong Hilir Ds. Ciwaruga \\ Bandung 40012. Email: study_lembur@yahoo.co.id, yackobastor@yahoo.com
}

\begin{abstract}
ABSTRAK
Kota Bandung adalah ibu kota Provinsi Jawa Barat menjadi sumber tarikan di sektor pendidikan, perdagangan, industri, pariwisata, kuliner, fashion dan sektor lainnya, menyebabkan banyak aktivitas yang terjadi yang berdampak pada kemacetan terutama di wilayah Bandung Tengah.

Penelitian ini membahas mengenai analisis kapasitas di ruas jalan Ahmad Yani dan jalan Buah Batu yang sudah mulai mengalami kemacetan berdasarkan hasil pengamatan di lapangan dan proyeksi volume lalu lintas tahun 2015 dan 2020. Analisis kapasitas dilakukan mengacu pada MKJI'1997 menggunakan data lalu lintas tahun 2012 dari Dinas Perhubungan Kota Bandung.

Didapatkan nilai derajat kejenuhan (DS) jalan Ahmad Yani $=1,35$ dan Buah Batu=1,36. Solusi dilakukan dengan cara membuat 5 (lima) skenario untuk jalan Ahmad Yani dan 13 skenario untuk jalan Buah Batu yang ditampilkan dalam Sistem Informasi Geografis (SIG).
\end{abstract}

Kata kunci : derajat kejenuhan, kemacetan, sistem informasi geografis (SIG) 


\section{Pendahuluan}

Kota Bandung merupakan salah satu kota di Indonesia dengan jumlah aktivitas masyarakat yang terbilang tinggi, hal ini terjadi karena banyaknya sumber tarikan yang mendorong masyarakat untuk bergerak dalam melakukan aktivitasnya. Sektor yang menyebabkan tarikan diantaranya adalah adanya tarikan dikarenakan pemerintahan yaitu Bandung merupakan ibu kota Jawa Barat sehingga pusat kegiatan pemerintahan terjadi di kota Bandung, kemudian sektor pariwisata yang merupakan destinasi masyarakat lokal maupun internasional, sektor pendidikan dan lain sebagainya. Tingginya tarikan di kota Bandung menyebabkan pergerakan masyarakat jauh lebih besar dibandingkan dengan kota-kota kecil lainnya. Kondisi kemacetan di Kota Bandung dapat dilihat pada gambar 1.

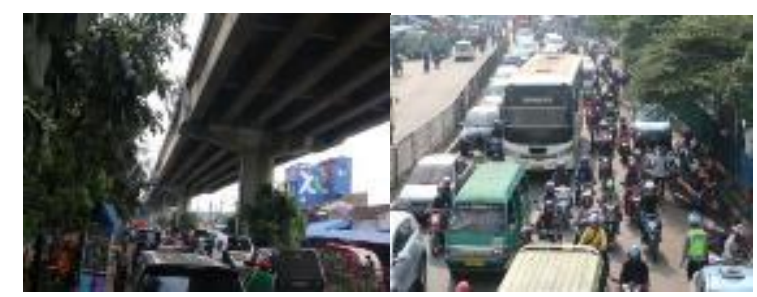

Gambar 1. Kondisi jalan kota Bandung

Kondisi jalan Kiara Condong (kiri) memperlihatkan bahwa adanya flyover yang dibangun tidak terlalu mempengaruhi kemacetan yang berada dibawahnya. Sedangkan jalan Cicaheum (kanan) memperlihatkan bahwa kondisi ruas jalan yang mengalami kemacetan hanya pada arah menuju kota Bandung, hal ini terjadi karena pengambilan gambar dilakukan pagi hari dimana tiap orang beraktivitas menuju pusat kota, berbeda dengan arah menuju keluar pusat kota yang terlihat jauh lebih renggang.

\section{Studi Pustaka}

Jalan adalah prasarana transportasi darat yang meliputi segala bagian jalan, termasuk bangunan pelengkap dan perlengkapannya yang diperuntukkan bagi lalu lintas, yang berada pada permukaan tanah, di atas permukaan tanah, di bawah permukaan tanah dan/atau air, serta di atas permukaan air, kecuali jalan kereta api, jalan lori, dan jalan kabel. Sedangkan Kapasitas jalan adalah kemampuan suatu ruas jalan untuk menampung arus atau volume lalu lintas yang ideal dalam satuan waktu tertentu, dinyatakan dalam jumlah kendaraan yang melewati potongan jalan tertentu dalam satu jam (kend/jam), atau dengan mempertimbangan berbagai jenis kendaraan yang melalui suatu jalan digunakan satuan mobil penumpang sebagai satuan kendaraan dalam perhitungan kapasitas maka kapasitas menggunakan satuan satuan mobil penumpang per jam atau (smp)/jam. Analisis kapasitas jalan yang dilakukan mengacu terhadap MKJI'1997 dimana pada perhitungannya membutuhkan data arus juga kapasitas jalan itu sendiri. Kapasitas jalan dapat dihitung dengan menggunakan rumus:

$\mathrm{C}=\mathrm{Co}_{\mathrm{F}} \times \mathrm{FC}_{\mathrm{W}} \times \mathrm{FC}_{\mathrm{SP}} \times \mathrm{FC}_{\mathrm{SF}} \times \mathrm{FC}_{\mathrm{CS}}$

Dimana:

$\mathrm{C}=$ kapasitas jalan (smp/jam)

Co $\quad=$ kapasitas dasar ( $\mathrm{smp} / \mathrm{jam})$

$\mathrm{FC}_{\mathrm{W}}=$ faktor penyesuaian kapasitas dasar

$\mathrm{FC}_{\mathrm{SP}}=$ faktor penyesuaian pemisah arah

$\mathrm{FC}_{\mathrm{SF}}=$ faktor penyesuaian hambatan samping

$\mathrm{FC}_{\mathrm{CS}}=$ faktor penyesuaian ukuran kota

Sedangkan data arus bias didapatkan dengan cara melakukan pengukuran langsung ataupun menggunakan data sekunder yang tersedia pada instansi-instansi terkait seperti Dinas Perhubungan. Kendaraan yang didapatkan pada hasil survei terdapat 8 golongan yang mengacu terhadap Pd.T-19-2004-B tentang survey pencacahan, data ini kemudian diolah menjadi 4 golongan saja sesuai dengan standard perhitungan analisis kapasitas jalan yang digunakan yaitu MKJI'1997, dimana setelah didapatkan data lalu lintas kemudian dikalikan dengan eqivalensi mobil penumpang. Barulah kemudian perhitungan nilai derajat kejenuhan yang dilakukan dalam analisis kapasitas jalan dapat dilakukan menggunakan rumus:

$\mathrm{DS}=\mathrm{Q} / \mathrm{C}$

Dimana:

Q $\quad=$ Volume kendaraan

$\mathrm{C}=$ Kapasitas jalan. 
Analisis kapasitas jalan yang digunakan kemudian diolah kembali untuk dijadikan Informasi Geospasial, dimana Informasi geospasial dapat diperoleh menggunakan metode survei pengukuran dan pemetaan secara langsung dilapangan (survei terestris) maupun secara tidak langsung di lapangan (remote sensing) menggunakan wahana pesawat udara dan satelit. Penggunaan metode remote sensing dilakukan untuk pemetaan wilayah yang cakupannya relatif luas seperti pemetaan jaringan jalan dan pemetaan batas wilayah.

\section{Pengadaan data}

Penginderaan jarak jauh menggunakan wahana satelit menghasilkan citra satelit yaitu data raster (gambar digital) yang memiliki koordinat bumi (georeferensi) seperti contoh pada Gambar 2.

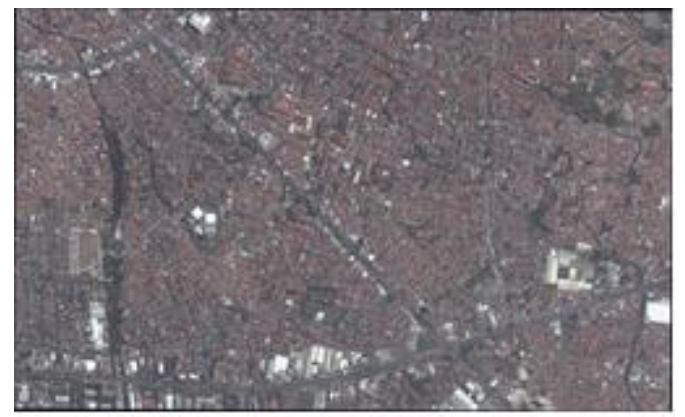

Gambar 2. Tampilan citra satelit

2. Pembuatan Peta digital

Uraian pembuatan peta digital dapat dilihat pada Gambar 3.

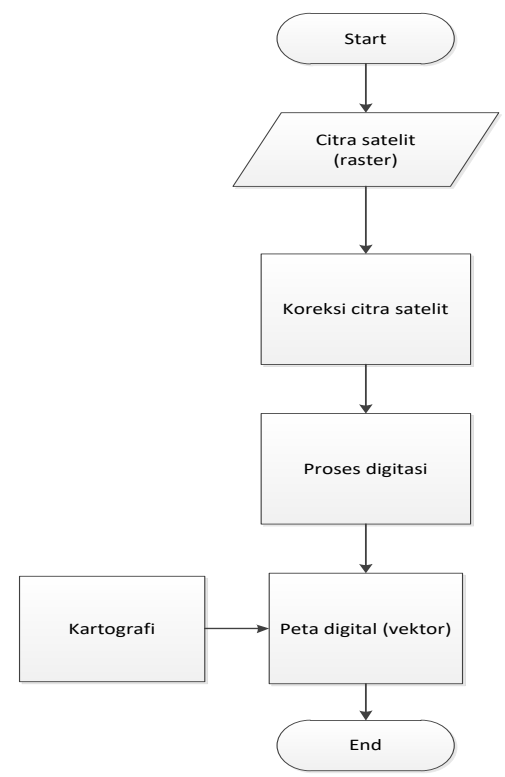

Gambar 3. Alur pembuatan peta digital tampilan gambar yang dimaksud dapat dilihat pada Gambar 4 dan 5.

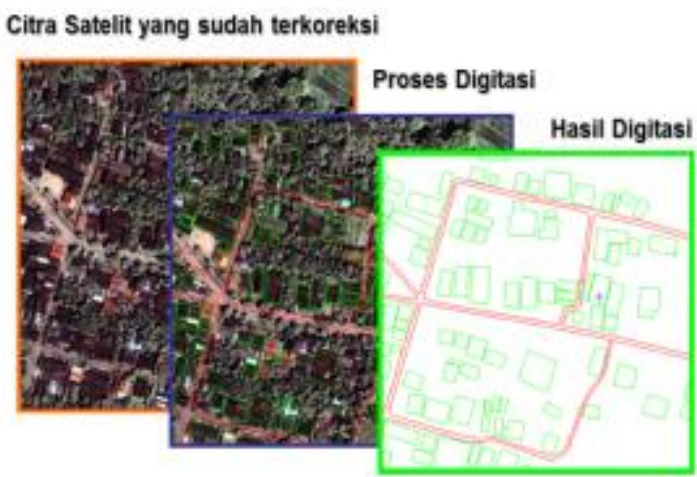

Gambar 4. Proses pembuatan peta digital

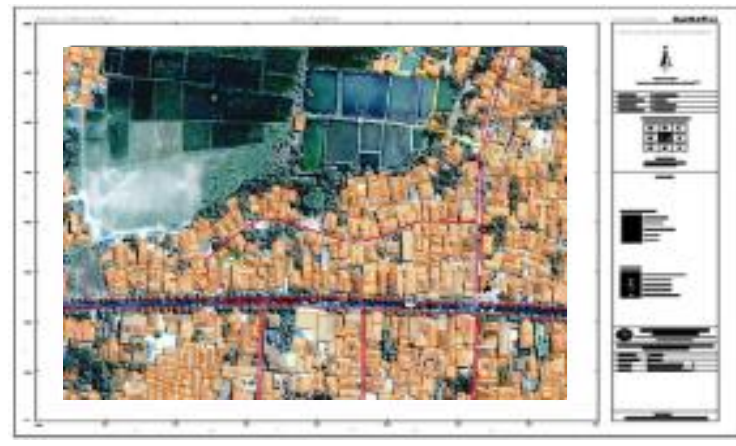

Gambar 5. Peta citra satelit setelah dilakukan kartografi.

Pembuatan informasi geospasial yang dilakukan dalam penelitian ini mempunyai korelasi dengan perhitungan analisis kapasitas jalan, dimana pada faktor-faktor perhitungan tersebut terdapat fungsi dari salah satu geospasial yaitu jaringan, jumlah penduduk dan kondisi tataguna lahan.

\section{III.Metodologi}

Metodologi adalah proses yang dilakukan untuk melakukan suatu kegiatan. Hal ini dilakukan agar tahapan-tahapan yang dilakukan memenuhi kriteria yang diharapkan, serta memberikan kemudahan kepada orang lain yang ingin mengetahui alur suatu kegiatan yang akan dilakukan oleh seseorang. Tahapan analisis perancangan ini ditampilkan pada Gambar 6.

Setelah dilakukan tahapan tersebut maka 


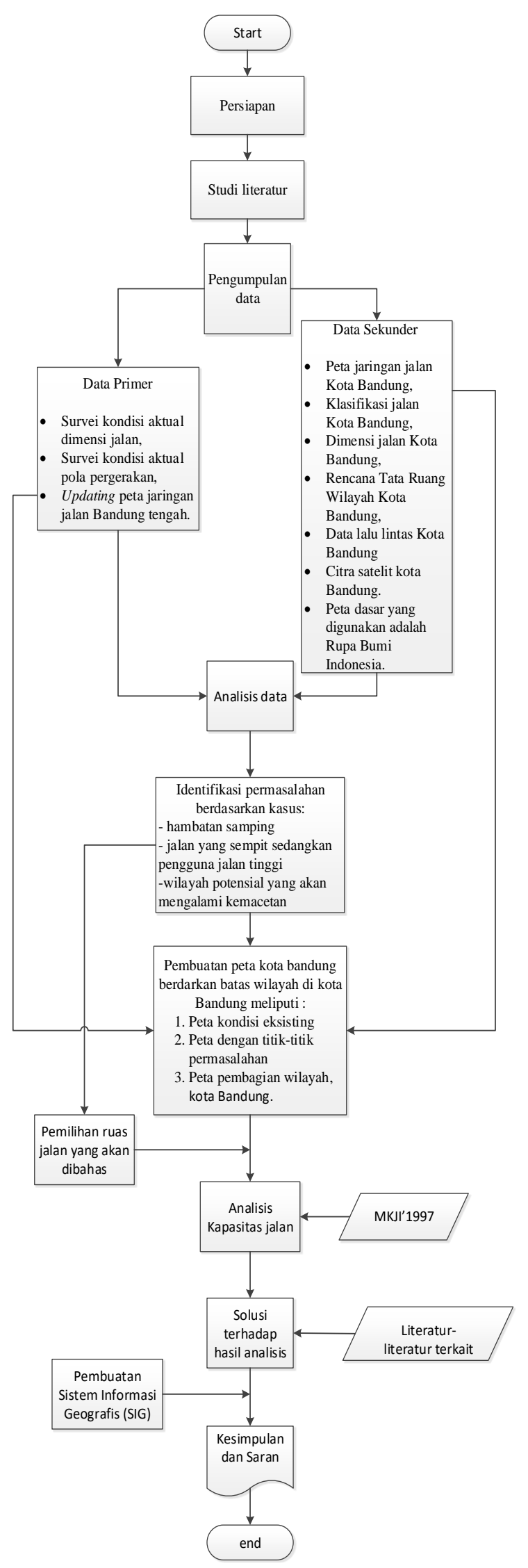

\section{IV.Analisis dan Pembahasan}

Pada penelitian ini yang pertama kali dilakukan adalah Pembagian wilayah kota Bandung

Dimana berdasarkan penelusuran lapangan terhadap instansi terkait yang berhubungan dengan pembagian wilayah ini, maka dapat dijelaskan bahwa kota Bandung dibagi berdasarkan Samsat dan Bappeda.

\section{Pembagian wilayah samsat}

Pembagian wilayah yang dilakukan oleh samsat berdasarkan pada wilayah kerja kepolisian dan letak geografis wilayah Kota Bandung, berdasarkan data tersebut maka Kota Bandung di bagi menjadi 3 (tiga) bagian wilayah, yaitu : Bandung Barat, Bandung Tengah dan Bandung Selatan dimana masing-masing wilayah memiliki daerah pengawasannya masingmasing. Hal ini dapat dilihat pada Gambar 7.

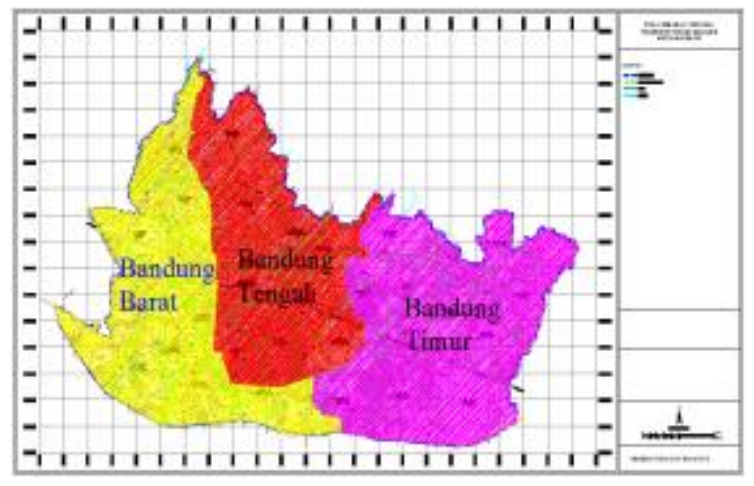

Gambar 7. Pembagian wilayah kota Bandung (samsat)

\section{Pembagian wilayah Bappeda}

Pembagian wilayah yang di lakukan ini sesuai dengan namanya maka mengacu terhadap instansi terkait yaitu Bappeda. Menurut Bappeda bandung dibagi menjadi 2 pusat pelayanan yaitu Alun-alun dan Gedebage dimana tiap pusat pelayanan menaungi beberapa Sub wilayah kota (SWK) dan 1(satu) SWK merupakan gabungan dari beberapa kecamatan. Agar lebih jelas, pembagian wilayah berdasarkan Bappeda ini dapat dilihat pada Gambar 8.

Gambar 6. Metodologi penelitian 


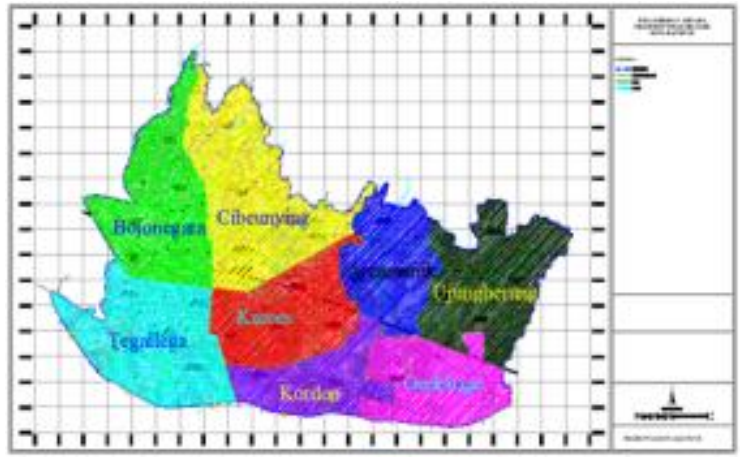

Gambar 8. Pembagian wilayah kota Bandung (Bappeda)

Berdasarkan data yang telah didapatkan dan dianalisis, maka dapat disimpulkan bahwa menurut RTRW Kota Bandung, wilayah Bandung Tengah yang dikelola oleh Samsat merupakan daerah pendidikan, perdagangan, industri dan perumahan, wilayah Bandung Barat merupakan daerah industri dan pergudangan, serta wilayah Bandung timur merupakan daerah perumahan.

\section{Wilayah Bandung Tengah}

Wilayah Bandung tengah yang digunakan pada penelitian ini mengacu terhadap Samsat karena lebih sesuai dengan konten studi yang akan dilakukan, dimana Bandung tengah menurut Samsat ini merupakan kumpulan dari 9 kecamatan. Selain itu pemilihan wilayah Bandung tengah ini dilakukan karena melihat potensi kemacetan yang lebih besar dibandingkan dengan wilayah lainnya, hal ini di tunjang dengan banyaknya aktivitas yang terjadi, dimulai dari pendidikan, perkantoran, wisata dan aktivitas lainnya yang berada di wilayah Bandung tengah ini. Untuk mengetahui besar dan kondisi wilayah Bandung Tengah saja, dapat dilihat pada Gambar 9.

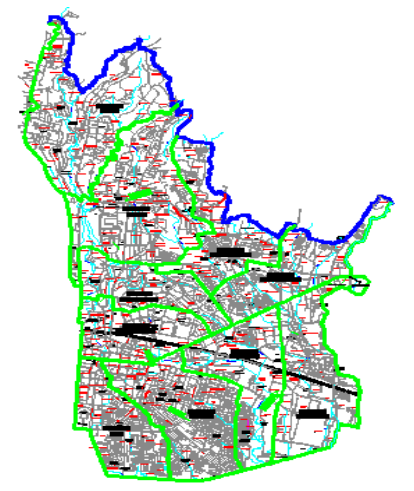

\section{BANDUNG TENGAH}

Gambar 9. Wilayah Bandung Tengah

\section{Kondisi ruas jalan Bandung Tengah}

Berdasarkan data yang telah didapatkan dari Dinas Perhubungan (Dishub), baik itu data tertulis ataupun hasil wawancara dengan pihak terkait maka didapatkan nilai derajat kejenuhan pada ruas jalan di Bandung Tengah, hal ini memperkuat pernyataan bahwa wilayah Bandung Tengah sudah mulai banyak mengalami kemacetan, hasil ini didapatkan dari Dishub berdasarkan penelitian yang dilakukan menggunakan pendekatan Saturn. Kondisi ruas jalan di Kota Bandung dapat dilihat pada Gambar 10.

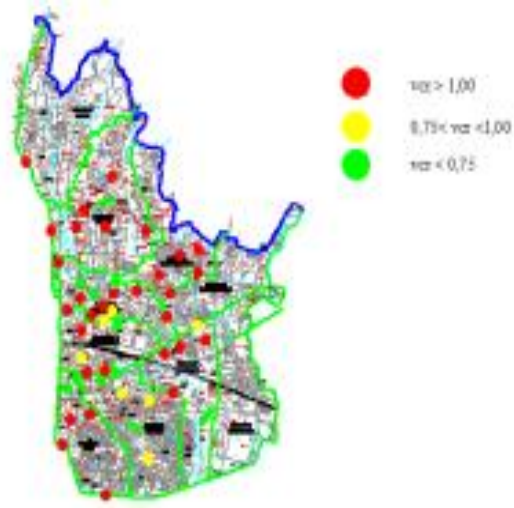

\section{KONDISI RUAS JALAN BANDUNG TENGAH}

Gambar 10. Kondisi ruas jalan Bandung Tengah

\section{Pemilihan ruas jalan}

Pemilihan ruas jalan yang akan dijadikan lokasi tinjauan dipilih berdasarkan potensi kemacetan yang akan terjadi di masa yang akan datang, hal ini dapat dilihat dari kondisi tata guna lahan, banyaknya kendaraan dan hasil pengamatan lapangan yang terjadi saat ini, selain itu faktor kelengkapan data yang didapatkan juga menjadi salah satu faktor pemilihan ruas jalan ini. Proses pemilihan ini dimulai dari inventarisasi jalan di Bandung Tengah menggunakan bantuan google map dan data dari dishub, yang kemudian di diklasifikasikan berdasarkan kelengkapan data, serta kondisi ruas jalan yang akan di tinjau. Berdasarkan hasil analisis tersebut maka terpilihlah 2 ruas jalan yang menjadi tinjauan yaitu jalan Ahmad Yani dan Jalan Buah Batu. 


\section{Deskripsi jalan Ahmad Yani}

Jalan Ahmad Yani merupakan jalan di kota Bandung dengan tipe jalan 4/1 UD, fungsi jalan Arteri sekunder, status jalan Nasional dan lebar jalan $15 \mathrm{~m}$ serta panjang jalan $\pm 1,14 \mathrm{Km}$. Jalan Ahmad Yani ini sebelah Barat berbatasan dengan jalan Jakarta, Supratman dan Ahmad Yani itu sendiri, sedangkan sebelah Timur berbatasan dengan jalan Ibrahim Adjie dan jalan Cicadas. Jalan Ahmad Yani ini merupakan salah satu jalan yang sudah mulai mengalami permasalahan berdasarkan data yang didapatkan dari Dinas Perhubungan dan hasil pengamatan lapangan secara langsung. Dugaan sementara penyebab kemacetan ini adalah pasar yang terletak di area Jalan Ahmad Yani, fasilitas on street parking dan tentu saja besarnya volume kendaraan yang melintasi wilayah tersebut. Berdasarkan kondisi tersebut maka perlu dilakukan analisis untuk memprediksi kemacetan yang akan terjadi di masa yang akan datang. Peta jalan Ahmad Yani dapat dilihat ada Gambar 11.

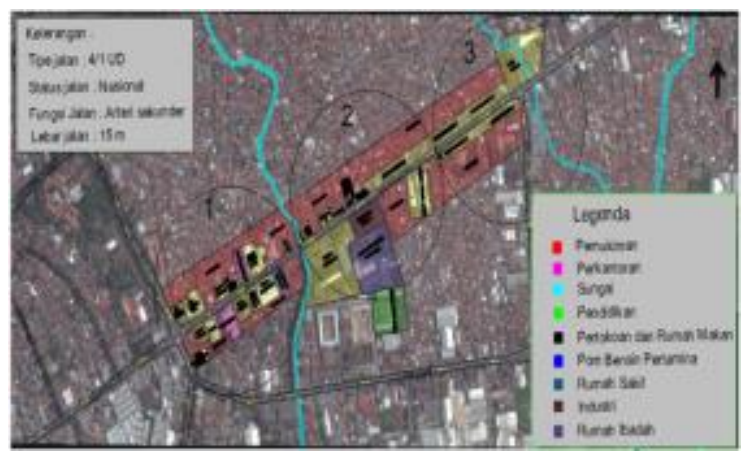

Gambar 11. Peta Jalan Ahmad Yani

\section{Deskripsi jalan Buah Batu}

Jalan Buah Batu merupakan jalan di kota Bandung dengan tipe jalan 4/2 UD, fungsi jalan Kolektor sekunder, status jalan Kota Bandung dan lebar jalan $13 \mathrm{~m}$ serta panjang jalan $\pm 1,70$ $\mathrm{Km}$. Kendaraan yang masuk jalan Buah Batu merupakan kendaraan yang berasal dari jalan Pelajar Pejuang 45, jalan BKR, jalan Soekarno Hatta dan jalan Terusan Buah Batu. Fungsi guna lahan dari jalan Buah Batu ini cukup beraneka ragam, dimulai dari perdagangan, perkantoran, perumahan dan pendidikan. Letak jalan Buah Batu yang cukup strategis kerap kali menjadi pusat tarikan tersendiri, hal ini dapat dilihat dari kemudahannya mencapai tempat yang sering dikunjungi, seperti jalan tol, tempat hiburan, ataupun wilayah perkantoran dan pendidikan. Selain tarikan sebagai akses penghubung, disepanjang jalan Buah Batu juga terdapat banyak sekali pusat tarikan seperti rumah makan, supermarket, kantor dan lain sebagainya hal ini diprediksi akan membuat jalan ini semakin sering dilewati oleh kendaraan dalam skala yang banyak dan berpotensi menyebabkan kemacetan, oleh karena itu jalan ini perlu dilakukan analisis untuk mengetahui kondisinya dimasa yang akan datang. Peta jalan Buah Batu dapat dilihat ada Gambar 12.

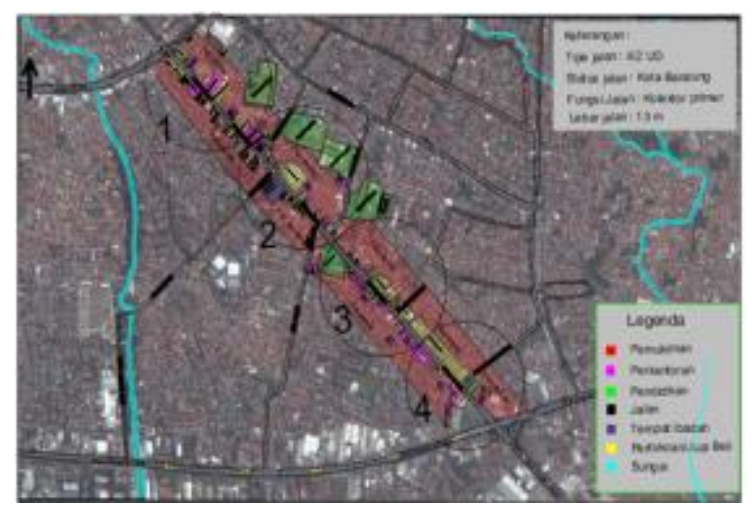

Gambar 12. Peta Jalan Buah Batu

\section{Analisis Kapasitas Ruas Jalan}

Analisis kapasitas yang dilakukan pada penelitian ini menggunakan data sekunder berupa hasil pengamatan yang pernah dilakukan, sehingga data lalu lintas yang dibutuhkan sudah tersedia, hanya saja data yang didapatkan adalah data tahun 2012 sehingga perlu diolah terlebih dahulu agar didapatkan kondisi jalan pada saat ini (tahun 2015) kemudian di proyeksikan ke tahun 2020. Data lalu lintas yang telah didapatkan kemudian diolah untuk mengetahui kondisi jalan yang ditinjau dalam bentuk derajat kejenuhan.

\section{Analisis kapasitas pada ruas jalan Ahmad Yani}

Berdasarkan MKJI'1997 dan kondisi lapangan maka data-data untuk menghitung kapasitas jalan dapat ditentukan yaitu:

$$
\begin{array}{ll}
\mathrm{Co} & =1650 \times 4 \text { (lajur) }=6600 \mathrm{smp} / \mathrm{jam} \\
\mathrm{FCw} & =1,04 \\
\mathrm{FCsp} & =1,00
\end{array}
$$


FCsf $=0,84$

$\mathrm{FCcs}=1,00$

Dengan menggunakan data diatas maka perhitungan kapasitas dasar ruas jalaan Ahmad Yani dapat diketahui, yaitu:

$$
\begin{aligned}
\mathrm{C} & =\mathrm{Co} \times \mathrm{FCw} \times \mathrm{FCsp} \times \mathrm{FCsf} \times \mathrm{FCcs} \\
& =6600 \times 1,04 \times 1,00 \times 0,84 \times 1,00 \\
& =5765,76 \mathrm{smp} / \mathrm{jam}
\end{aligned}
$$

Setelah dilakukan perhitungan kapasitas dasar lalu dilakukanlah perhitungan arus yang ada dalam satuan mobil penumpang (smp). Hal-hal yang harus dilakukan untuk menghitung arus ini adalah:

- Mengklasifikasikan hasil survey lalu lintas, dari 8 golongan menjadi 4 golongan (LV,HV,MC).

- Menentukan jam puncak pada ruas jalan Ahmad Yani.

- Konversi dari kendaraan/jam menjadi satuan mobil penumpang/jam (smp/jam).

Pengklasifikasian dilakukan berdasarkan MKJI'1997 yaitu yang merupakan LV (kendaraan ringan) meliputi: mobil penumpang, oplet, mikrobis, pick-up dan truk kecil sesuai sistim klasifikasi Bina Marga, sedangkan HV (kendaraan berat) meliputi bis, truk 2 as, truk 3 as dan truk kombinasi sesuai sistim klasifikasi Bina Marga), sedangkan MC adalah kendaraan roda 2 atau motor.

Penentuan jam puncak sendiri dilakukan dengan cara menjumlahkan terlebih dahulu arus kendaraaan tiap masing-masing klasifikasinya per 1 jam sehingga jumlah kendaraan yang dihitung menjadi kend/jam, setelah itu penentuan jam puncak dapat dilakukan dengan menjumlahkan kendaraaan ( $\mathrm{LV}, \mathrm{HV}, \mathrm{MC})$ pada tiap jamnya, contohnya 05.00-06.00, 06.0007.00 dan seterusnya. Data hasil penjumlahan dan penentuan jam puncak ini dapat dilihat pada Tabel 1 .

Tabel 1. Penentuan Jam Puncak

\begin{tabular}{|c|r|r|r|r|}
\hline $\begin{array}{c}\text { Waktu } \\
(\mathbf{1 5} \text { menitan })\end{array}$ & $\begin{array}{c}\text { LV } \\
\text { (kend/jam) }\end{array}$ & $\begin{array}{c}\text { HV } \\
\text { (kend/jam) }\end{array}$ & $\begin{array}{c}\text { MC } \\
\text { (kend/jam) }\end{array}$ & $\begin{array}{c}\text { Jumlah } \\
\text { (kend/jam) }\end{array}$ \\
\hline $05.00-06.00$ & 434 & 40 & 943 & 1417 \\
\hline $05.15-06.15$ & 492 & 46 & 1226 & 1764 \\
\hline $05.30-06.30$ & 690 & 50 & 1630 & 2370 \\
\hline $05.45-06.45$ & 887 & 62 & 2228 & 3177 \\
\hline $06.00-07.00$ & 1068 & 60 & 2792 & 3920 \\
\hline $06.15-07.15$ & 1392 & 58 & 3171 & 4621 \\
\hline $06.30-07.30$ & 1480 & 61 & 3485 & 5026 \\
\hline $06.45-07.45$ & 1573 & 69 & 3860 & 5502 \\
\hline $07.00-08.00$ & 1655 & 80 & 4331 & 6066 \\
\hline $07.15-08.15$ & 1639 & 88 & 4459 & 6186 \\
\hline $07.30-08.30$ & 1806 & 104 & 4340 & 6250 \\
\hline $07.45-08.45$ & 1748 & 106 & 3701 & 5555 \\
\hline
\end{tabular}

\begin{tabular}{|c|c|c|c|c|}
\hline $08.00-09.00$ & 1658 & 106 & 2976 & 4740 \\
\hline $08.15-09.15$ & 1572 & 120 & 2630 & 4322 \\
\hline $08.30-09.45$ & 1421 & 129 & 2398 & 3948 \\
\hline $08.45-09.45$ & 1404 & 133 & 2165 & 3702 \\
\hline $09.00-10.00$ & 1360 & 124 & 1845 & 3329 \\
\hline $09.15-10.15$ & 1367 & 126 & 1781 & 3274 \\
\hline $09.30-10.30$ & 1348 & 121 & 1701 & 3170 \\
\hline $09.45-10.45$ & 1365 & 124 & 1919 & 3408 \\
\hline $10.00-11.00$ & 1427 & 133 & 2199 & 3759 \\
\hline $10.15-11.15$ & 1424 & 135 & 2254 & 3813 \\
\hline $10.30-11.30$ & 1446 & 126 & 2613 & 4185 \\
\hline $10.45-11.45$ & 1502 & 123 & 2845 & 4470 \\
\hline $11.00-12.00$ & 1596 & 122 & 3374 & 5092 \\
\hline $11.15-12.15$ & 1769 & 123 & 3821 & 5713 \\
\hline $11.30-12.30$ & 1777 & 141 & 4176 & 6094 \\
\hline $11.45-12.45$ & 1893 & 135 & 4623 & 6651 \\
\hline $12.00-13.00$ & 1955 & 141 & 4674 & 6770 \\
\hline $12.15-13.15$ & 1849 & 135 & 5092 & 7076 \\
\hline $12.30-13.30$ & 1443 & 89 & 3858 & 5390 \\
\hline $12.45-13.45$ & 927 & 61 & 2600 & 3588 \\
\hline $13.00-14.00$ & 887 & 61 & 2898 & 3846 \\
\hline $13.15-14.15$ & 887 & 50 & 2656 & 3593 \\
\hline $13.30-14.30$ & 1462 & 77 & 3668 & 5207 \\
\hline $13.45-14.45$ & 1807 & 115 & 4713 & 6635 \\
\hline $14.00-15.00$ & 1648 & 110 & 4525 & 6283 \\
\hline $14.15-15.15$ & 1413 & 105 & 4147 & 5665 \\
\hline $14.30-15.30$ & 1099 & 95 & 4126 & 5320 \\
\hline $14.45-15.45$ & 1002 & 73 & 4393 & 5468 \\
\hline $15.00-16.00$ & 1120 & 66 & 3962 & 5148 \\
\hline $15.15-16.15$ & 1353 & 74 & 4399 & 5826 \\
\hline $15.30-16.30$ & 1657 & 74 & 4506 & 6237 \\
\hline $15.45-16.45$ & 1952 & 81 & 4600 & 6633 \\
\hline $16.00-17.00$ & 2348 & 88 & 5634 & 8070 \\
\hline $16.15-17.15$ & & & & \\
\hline $16.30-17.30$ & & & & \\
\hline $16.45-17.45$ & & & & \\
\hline & & & & \\
\hline
\end{tabular}

Jam puncak yang didapatkan pada jalan Ahmad Yani terjadi pada pukul 16.00-17.00 dimana jumlah kendaraannya adalah $8070 \mathrm{kend} / \mathrm{jam}$.

Setelah jam puncak telah diketahui maka jumlah arusnya pun diketahui, hanya saja satuan dari arus tersebut adalah kendaraan/jam, hal ini menyebabkan perhitungan nilai derajat kejenuhan belum bisa dilakukan, karena satuan yang didapat adala satuan mobil penumpang (smp/jam). Oleh karena itu dilakukanlah sebuah konversi dengan mengkalikan data kend/jam dengan ekivalensi kendaraannya yang ada pada MKJI'1997. Didapatkanlah jumlah arus jalan Ahmad Yani adalah 4716 smp/jam.

Perhitungan nilai DS pada tahun 2012 dapat dilakukan yaitu:

$$
\begin{aligned}
\mathrm{DS}_{2012} & =\mathrm{Q} / \mathrm{C} \\
& =4716 / 5765,76 \\
& =0,817>0,75
\end{aligned}
$$

Untuk mendapatkan kondisi ruas jalan pada tahun 2015 maka perlu dilakukan proyeksi, hal ini dilakukan dengan cara mengkalikan arus kendaraan pada tahun 2012 dengan angka pertumbuhan kendaraannya yang didapat dari Badan Pusat Statistik (BPS), dimana data dari BPS dapat dilihat pada Tabel II. 
Tabel II. Angka Pertumbuhan Kendaraan

\begin{tabular}{|c|c|c|c|}
\hline No & Tahun & $\begin{array}{c}\text { Volume lalu } \\
\text { lintas } \\
\text { (kendaraan) }\end{array}$ & $\begin{array}{l}\text { Pertumbuhan } \\
\text { kendaraan (\%) }\end{array}$ \\
\hline 1 & 2011 & 1.196 .813 & \\
\hline 2 & 2012 & 1.252 .230 & 4,63 \\
\hline 3 & 2013 & 1.355 .815 & 8,27 \\
\hline 4 & 2014 & 1.443 .217 & 6,45 \\
\hline \multicolumn{3}{|c|}{ Rata-rata } & 6,45 \\
\hline
\end{tabular}

Maka jumlah arus pada tahun 2015 adalah:

Volume kendaraan (LV) $2015=2348 *(1+6,45 \%)^{3}$

$$
=2832,273 \mathrm{smp} / \mathrm{jam}
$$

Volume kendaraan (HV) $2015=114,4 *(1+6,45 \%)^{3}$

$$
=137,99 \mathrm{smp} / \mathrm{jam}
$$

Volume kendaraan $(\mathrm{MC}) 2015=2253,6 *(1+6,45 \%)^{3}$

$$
=2718,403 \mathrm{smp} / \mathrm{jam}
$$

Maka nilai derajat kejenuhan pada tahun 2015 dapat dihitung sebagai berikut:

$$
\begin{aligned}
\mathrm{DS}_{2015} & =\mathrm{Q} / \mathrm{C} \\
& =5688,671 / 5765,76 \\
& =0,99>0,75
\end{aligned}
$$

Dengan memiliki data pada tahun 2015 maka dapat dilakukan proyeksi terhadap kondisi 5 tahun yang akan datang, perhitungan volume kendaraan adalah sebagai berikut:

Volume kendaraan $\left(\right.$ LV) $2020=2832,2 *(1+6,45 \%)^{5}$

$$
=3871,36 \mathrm{smp} / \mathrm{jam}
$$

Volume kendaraan (HV) $2020=137,99 *(1+6,45 \%)^{5}$

$$
=188,62 \mathrm{smp} / \mathrm{jam}
$$

Volume kendaraan (MC) $2020=2718,4 *(1+6,45 \%)^{5}$

$$
=3715,71 \mathrm{smp} / \mathrm{jam}
$$

Nilai DS pada tahun 2020 dapat dihitung menggunakan data arus yang sudah didapatkan yaitu $3871,36+188,62+3715,71=7775,69$ smp/jam. Maka nilai derajat kejenuhan pada tahun 2015 adalah:

$$
\begin{aligned}
\mathrm{DS}_{2020} & =\mathrm{Q} / \mathrm{C} \\
& =7775,69 / 5765,76 \\
& =1,35>0,75
\end{aligned}
$$

\section{Analisis kapasitas pada ruas jalan Buah Batu}

Analisis yang dilakukan pada jalan Buah Batu sama dengan jalan Ahmad Yani, yaitu mengacu terhadap MKJI'1997, dimlai dari penentuan kapasitas dasar, jumlah arus, jam puncak, menentukan nilai DS dan memproyeksikannya ke tahun 2020, yang berbeda adalah arus yang dihitung harus dijumlahkan terlebih dahulu karena tipe jalannya adalah 4/2 UD sehingga ada 2 arus kendaraan pada 1 ruas jalan Buah

\begin{tabular}{|c|c|c|c|c|}
\hline $\begin{array}{c}\text { Waktu } \\
\text { (15 menitan) }\end{array}$ & $\begin{array}{c}\text { LV } \\
\text { (kend/jam) }\end{array}$ & $\begin{array}{c}\text { HV } \\
\text { (kend/jam) }\end{array}$ & $\begin{array}{c}\mathrm{MC} \\
\text { (kend/jam) }\end{array}$ & $\underset{\text { (kend/jam) }}{\text { Jumlah }}$ \\
\hline $05.00-06.00$ & 521 & 91 & 1385 & 1997 \\
\hline $05.15-06.15$ & 792 & 119 & 1949 & 2860 \\
\hline $05.30-06.30$ & 1062 & 143 & 2934 & 4139 \\
\hline $05.45-06.45$ & 1294 & 163 & 5330 & 6787 \\
\hline $06.00-07.00$ & 1403 & 162 & 6476 & 8041 \\
\hline $06.15-07.15$ & 1374 & 151 & 7604 & 9129 \\
\hline $06.30-07.30$ & 1306 & 140 & 8504 & 9950 \\
\hline $06.45-07.45$ & 1181 & 136 & 8402 & 9719 \\
\hline $07.00-08.00$ & 1136 & 133 & 9458 & 10727 \\
\hline $07.15-08.15$ & 1075 & 120 & 10324 & 11519 \\
\hline $07.30-08.30$ & 1067 & 126 & 10724 & 11917 \\
\hline $07.45-08.45$ & 1159 & 126 & 10301 & 11586 \\
\hline $08.00-09.00$ & 1601 & 132 & 9675 & 11408 \\
\hline $08.15-09.15$ & 1829 & 147 & 8529 & 10505 \\
\hline $08.30-09.45$ & 1951 & 145 & 7609 & 9705 \\
\hline $08.45-09.45$ & 1952 & 131 & 6630 & 8713 \\
\hline $09.00-10.00$ & 1613 & 123 & 5662 & 7398 \\
\hline $09.15-10.15$ & 1552 & 107 & 5421 & 7080 \\
\hline $09.30-10.30$ & 1477 & 98 & 6241 & 7816 \\
\hline $09.45-10.45$ & 1454 & 104 & 6356 & 7914 \\
\hline $10.00-11.00$ & 1457 & 105 & 6426 & 7988 \\
\hline $10.15-11.15$ & 1434 & 105 & 6116 & 7655 \\
\hline $10.30-11.30$ & 1445 & 107 & 4631 & 6183 \\
\hline $10.45-11.45$ & 1465 & 95 & 4259 & 5819 \\
\hline $11.00-12.00$ & 1453 & 82 & 3759 & 5294 \\
\hline $11.15-12.15$ & 1406 & 84 & 4061 & 5551 \\
\hline $11.30-12.30$ & 1381 & 72 & 4174 & 5627 \\
\hline $11.45-12.45$ & 1388 & 75 & 4208 & 5671 \\
\hline $12.00-13.00$ & 1377 & 83 & 4545 & 6005 \\
\hline $12.15-13.15$ & 1387 & 78 & 4162 & 5627 \\
\hline $12.30-13.30$ & 1411 & 77 & 4141 & 5629 \\
\hline $12.45-13.45$ & 1411 & 84 & 4049 & 5544 \\
\hline $13.00-14.00$ & 1455 & 83 & 3901 & 5439 \\
\hline $13.15-14.15$ & 1496 & 92 & 3820 & 5408 \\
\hline $13.30-14.30$ & 1553 & 112 & 3767 & 5432 \\
\hline
\end{tabular}
Batu. Sehingga didapatkanlah hasil dari analisis jalan Buah Batu adalah sebagai berikut:

Berdasarkan data dari MKJI'1997 yaitu:

$$
\begin{array}{ll}
\mathrm{Co} & =1500 \times 4 \text { (lajur) }=6000 \mathrm{smp} / \mathrm{jam} \\
\mathrm{FCw} & =0,95 \\
\mathrm{FCsp} & =0,88 \\
\mathrm{FCsf} & =0,95 \\
\mathrm{FCcs} & =1,00
\end{array}
$$

Maka nilai kapasitas dasar jalan Buah Batu adalah:

$$
\begin{aligned}
\mathrm{C} & =\mathrm{Co} \times \mathrm{FCw} \times \mathrm{FCsp} \times \mathrm{FCsf} \times \mathrm{FCcs} \\
& =6000 \times 0,95 \times 0,87 \times 0,95 \times 1,00 \\
& =4711,05 \mathrm{smp} / \mathrm{jam}
\end{aligned}
$$

Arus dan jam puncak adalah $11917 \mathrm{kend} / \mathrm{jam}$ pada pukul 07.30-08.30 hal ini dapat dilihat pada Tabel III.

Tabel III. Penentuan Jam Puncak 


\begin{tabular}{|c|r|r|r|r|}
\hline $13.45-14.45$ & 1610 & 117 & 3924 & 5651 \\
\hline $14.00-15.00$ & 1575 & 126 & 3933 & 5634 \\
\hline $14.15-15.15$ & 1598 & 121 & 3966 & 5685 \\
\hline $14.30-15.30$ & 1656 & 116 & 3801 & 5573 \\
\hline $14.45-15.45$ & 1609 & 113 & 3532 & 5254 \\
\hline $15.00-16.00$ & 1630 & 112 & 3436 & 5178 \\
\hline $15.15-16.15$ & 1592 & 106 & 3362 & 5060 \\
\hline $15.30-16.30$ & 1485 & 97 & 3581 & 5163 \\
\hline $15.45-16.45$ & 1396 & 87 & 3755 & 5238 \\
\hline $16.00-17.00$ & 1354 & 78 & 3960 & 5392 \\
\hline $16.15-17.15$ & & & & \\
\hline $16.30-17.30$ & & & & \\
\hline $16.45-17.45$ & & & & \\
\hline
\end{tabular}

Berdasarkan Tabel III maka dapat ditentukan bahwa jumlah kendaraan jalan Buah Batu adalah $1067+126+10724=11917 \mathrm{kend} / \mathrm{jam}$, lalu di konversikan terhadap satuan mobil penumpang sehingga didapatkan $1067+151+$ $2681=3899 \mathrm{smp} / \mathrm{jam}$.

Berdasarkan data arus diatas, maka perhitungan nilai derajat kejenuhan jalan Buah Batu pada tahun 2012 adalah sebagai berikut:

$$
\begin{aligned}
\text { DS } & =\mathrm{Q} / \mathrm{C} \\
& =3899 / 4711,05 \\
& =0,83>0,75
\end{aligned}
$$

Proyeksi ke tahun 2015 dilakukan dengan menggunakan angka pertumbuhan yang sama sehingga jumlah arus pada tahun 2015 adalah:

Volume kendaraan $(\mathrm{LV}) 2015=1067 *(1+6,45 \%)^{3}$

$$
=1287,07 \mathrm{smp} / \mathrm{jam}
$$

Volume kendaraan (HV) $2015=151 *(1+6,45 \%)^{3}$

$$
=182,14 \mathrm{smp} / \mathrm{jam}
$$

Volume kendaraan $(\mathrm{MC}) 2015=2681 *(1+6,45 \%)^{3}$

$$
=3233,95 \mathrm{smp} / \mathrm{jam}
$$

Berdasarkan data yang telah diproyeksikan, maka nilai arus menjadi: $1287,07+182,14+$ $3233,95=4703.16 \mathrm{smp} / \mathrm{jam}$ Maka nilai derajat kejenuhan pada tahun 2015 dapat dihitung sebagai berikut:

$$
\begin{aligned}
\mathrm{DS}_{2015} & =\mathrm{Q} / \mathrm{C} \\
& =3714,46 / 4711,05 \\
& =0,99>0,75
\end{aligned}
$$

Dengan memiliki data pada tahun 2015 maka dapat dilakukan proyeksi terhadap kondisi 5 tahun yang akan datang, perhitungan volume kendaraan adalah sebagai berikut:
Volume kendaraan (LV) 2020

$=1287,07 *(1+6,45 \%)^{5}$

$=1759,26 \mathrm{smp} / \mathrm{jam}$

Volume kendaraan (HV) 2020

$=182,14 *(1+6,45 \%)^{5}$

$=248,96 \mathrm{smp} / \mathrm{jam}$

Volume kendaraan (MC) 2020

$=3233,95 *(1+6,45 \%)^{5}$

$=4420,40 \mathrm{smp} / \mathrm{jam}$

Nilai DS pada tahun 2020 dapat dihitung menggunakan data arus yang sudah didapatkan yaitu $1759,26+248,96+4420,40=6428.62$ smp/jam. Maka nilai derajat kejenuhan pada tahun 2015 adalah:

$$
\begin{aligned}
\mathrm{DS}_{2020} & =\mathrm{Q} / \mathrm{C} \\
& =6428.62 / 4711,05 \\
& =1,36>0,75
\end{aligned}
$$

\section{Solusi hasil analisis}

Pembuatan alternatif solusi dilakukan dilakukan untuk menanggulangi kemungkinan kasus kemacetan yang akan terjadi di masa yang akan datang, alternative solusi yang akan dicoba merupakan manajemen lalu lintas dimana dengan menggunakan alternatif ini, diharapkan biaya yang dikeluarkan cenderung lebih sedikit. Solusi alternative akan coba direncanakan pada ruas jalan Ahmad Yani dan Buah Batu. Sedangkan ruas jalan yang digunakan untuk pembuatan Sistem Informasi Geospasial (SIG) hanya jalan Buah Batu saja, jalan ini dipilih berdasarkan beberapa pertimbangan yaitu kondisi tata guna lahan yang begitu variatif dan potensi perkembangan pertumbuhan kendaraan yang besar.

\section{Solusi Jalan Ahmad Yani}

Berdasarkan hasil analisis dapat diketahui bahwa nilai DS pada tahun 2020 mencapai angka 1,35 hal ini menjelaskan bahwa kondisi jalan ini sudah mengalami gangguan karena telah melebihi standar yang ditentukan yaitu $<1,00$. Berdasarkan hasil perhitungan inilah kemudian dilakukan percobaan penggunaan alternatif solusi untuk menyelesaikannya. 
a. Pembatasan arus masuk dari arah jalan Jakarta.

Dengan menggunakan alternatif ini diharapkan kendaraan yang masuk ke jalan Ahmad Yani dapat berkurang. Setelah melakukan Analisis maka didapatkanlah nilai DS setelah diterapkannya solusi ini adalah 1,21. Adapun gambar dari penerapan yang dimaksud dapat dilihat pada Gambar 13.

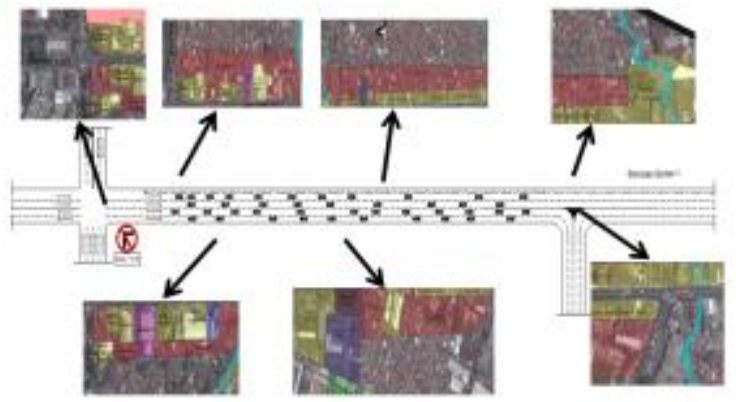

Gambar 13. Pembatasan arus masuk dari jalan

Jakarta.

\section{b. Penutupan arah menuju Cicaheum}

Penutupan kendaraan ini dilakukan untuk menghindari konflik yang ada di jalan ini tepatnya saat terjadi pemisahan antara kendaraan yang menuju jalan Ibrahim Adjie (belok kanan) dan Cicaheum (lurus), tidak jarang terdapat kendaraan yang berasal dari sebelah kanan yang seharusnya menuju jalan Ibrahim Adjie tiba-tiba berbelok menuju arah jalan Cicaheum, begitu juga sebaliknya. Hal ini tentu saja menyebabkan sebuah permasalahan baik dalam segi kelancaran lalu lintas ataupun keselamatan, oleh karena itu pada saat jam puncak kendaraan yang menuju cicaheum akan dialihkan menuju jalan PHH Mustafa, sedangkan jalan Ahmad Yani menjadi khusus untuk arah menuju jalan Ibrahim Adjie, dengan menerapkan solusi ini maka nilai DS menjadi 1,07. Solusi yang dimaksud dapat dilihat pada gambar 14.

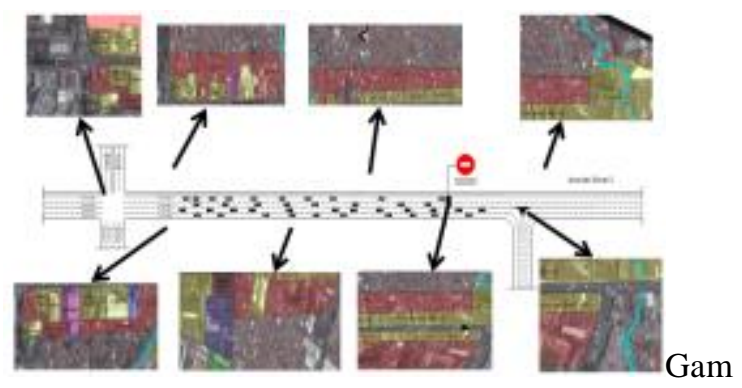

Gambar 14. Penutupan arah menuju Cicaheum

\section{c. Penghilangan Hambatan Samping}

Penghilangan Hambatan samping ini dilakukan untuk menambah kapasitas jalan Ahmad Yani. Adanya parking on street dijalan ini tak jarang menjadi salah satu penyebab kemacetan hal ini terjadi karena pergerakan pengendara yang akan parkir maupun keluar dapat menganggu lalu lintas yang ada di jalan Ahmad Yani, terutama dalam keadaan jam puncak. Dengan menerapkan solusi ini maka nilai DS menjadi 1,19. Adapun gambar dari solusi yang dimaksud dapat dilihat pada Gambar 15.

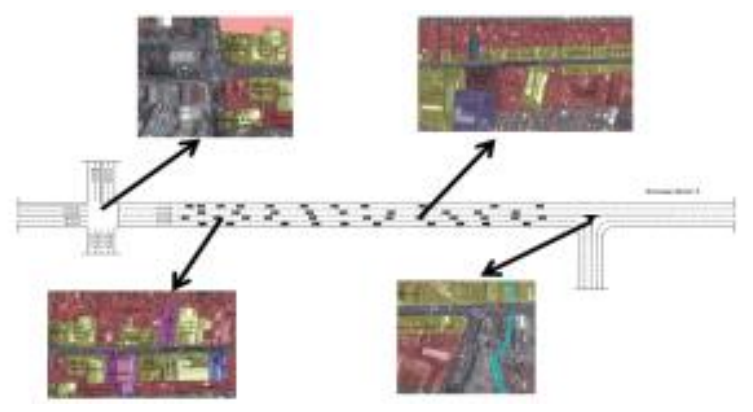

Gambar 15. Penghilangan hambatan samping.

d. Kombinasi Solusi a dan b

Pada solusi ini dicoba penggabungan solusi sebelumnya yaitu pembatasan arus yang masuk dari jalan Jakarta dan menghilangkan hambatan samping, dengan menggunakan solusi ini maka didapatkan nilai DSnya menjadi 1,07. Adapun yang dimaksud dalam solusi ini dapat dilihat pada Gambar 16.

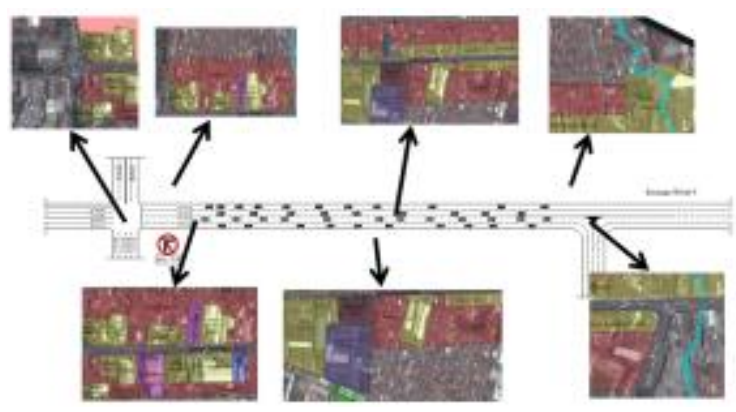

Gambar 16. Kombinasi solusi a dan c

e. Kombinasi solusi b dan c

Solusi gabungan kembali dilakukan untuk mendaptkan hasil yang maksimal, yaitu penutupan arus menuju Cicaheum dan penghilangan hambatan samping, hal ini diharapkan dapat mengurangi arus kendaraan yang menuju jalan Ahmad Yani secara drastis. Dengan menerapkan solusi ini maka didapatkan 
nilai DSnnya menjadi 0,76 . Adapun hal yang dimaksud dalam solusi ini dapat dilihat pada Gambar 17.

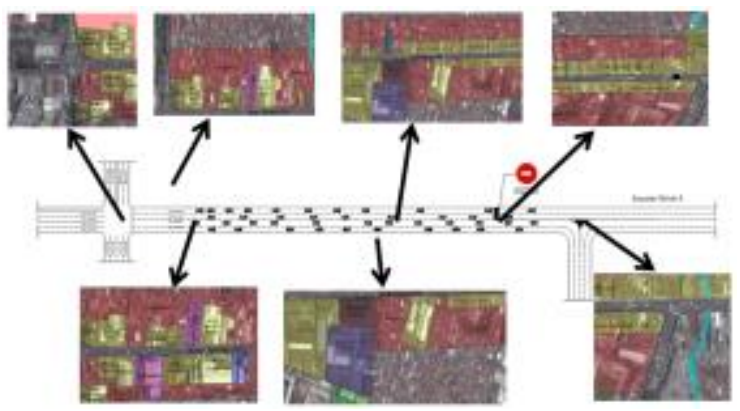

Gambar 17. Kombinasi solusi b dan c

\section{Solusi Jalan Buah Batu}

Berdasarkan hasil analisis, nilai DS jalan Buah Batu sudah mencapai angka 1,36 maka dilakukanlah percobaan penerapan alternatif solusi untuk menanggulangi kondisi ini. Adapun keterangan gambar yang akan diperlihatkan adalah warna hijau berarti lancar, kuning mulai mengalami kemacetan dan merah berada pada kondisi macet.

a. Melakukan sistem pengambilan lajur (contra flow)

Manajemen ini dilakukan terhadap ruas yang lebih dipenuhi kendaraan pada saat jam puncak, yaitu arah selatan menuju utara. Dengan menerapkan solusi ini maka didapatkan nilai DS untuk solusi ini menjadi 1,07. Adapun yang dimaksud pada solusi ini dapat dilihat pada Gambar 18.

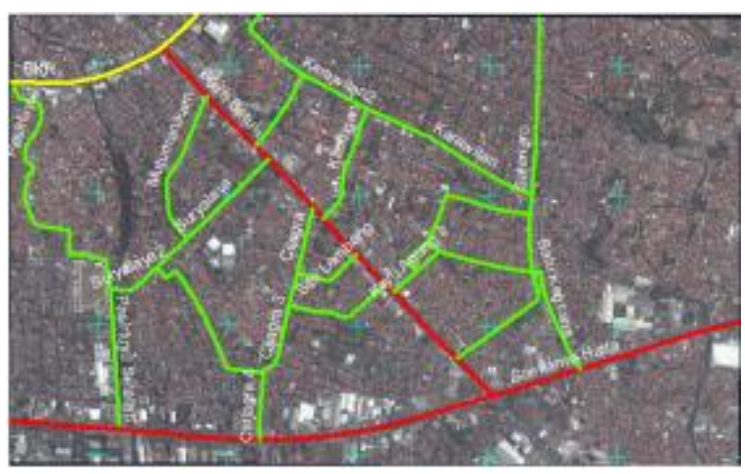

Gambar 18. Melakukan sistem contra flow.

\section{b. Melakukan Sistem 1 arah}

Solusi kedua yang coba dilakukan adalah penerapan sistem 1 arah untuk menanggulangi kemacetan ini, penerapan ini rencananya dilakukan hanya pada saat jam puncak saja, dimana kendaraan sedang berada pada kondisi yang sangat padat sehingga kapasitas jalan pada jalan Buah Batu ini dapat meningkat sebesar 2 kali lipat dari waktu biasa. Dengan menerapkan solusi ini maka didapatkan nilai DS untuk solusi ini menjadi 1,12. Adapun yang dimaksud pada solusi ini dapat dilihat pada Gambar 19.

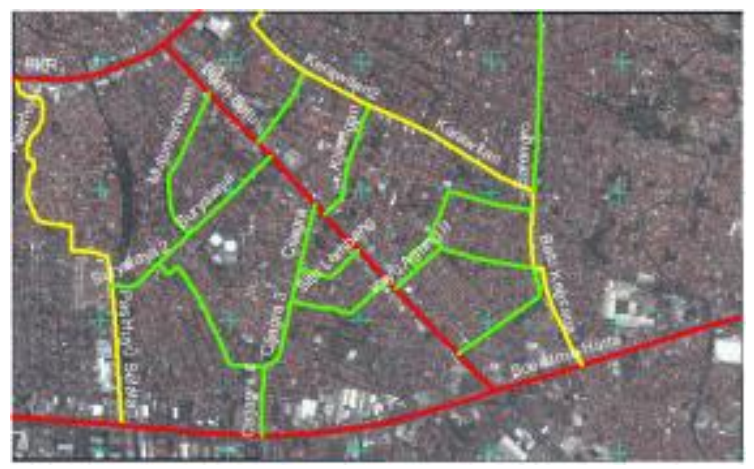

Gambar 19. Melakukan sistem satu arah

c. Menjadikan ruas jalan tersebut divided

Solusi ketiga yang coba diterapkan adalah melakukan perubahan pada ruas jalan yang tadinya undivided menjadi divided hal ini dilakukan karena banyaknya kendaraan yang sering melintas (memotong jalan) menyebabkan banyak konflik yang terjadi di ruas jalan ini, konflik yang terjadi di sekitar ruas jalan ini dikhawatirkan akan menganggu pengguna jalan yang sedang berlalu lalang di jalan Buah Batu. Dengan menerapkan solusi ini maka didapatkan nilai DS untuk solusi ini menjadi 1,21. Adapun yang dimaksud pada solusi ini dapat dilihat pada Gambar 20.

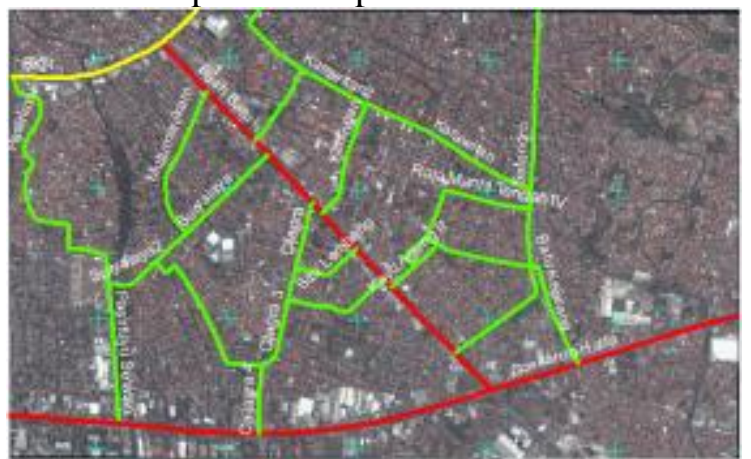

Gambar 20. Mengubah ruas menjadi divided.

d. Pengalihan arus menuju jalan Suryalaya.

Pada simulasi ini dicoba pengalihan arus hanya dilakukan pada ruas jalan Suryalaya, pengalihan ini dilakukan untuk kendaraan yang akan menuju jalan BKR, sehingga arus dari jalan Buah Batu dapat terbagi, rute yang digunakan adalah jalan Buah Batu - Suryalaya Pasir Luyu -BKR. Dengan menerapkan solusi ini maka didapatkan nilai DS untuk solusi ini menjadi 1,30. Adapun yang dimaksud pada solusi ini dapat dilihat pada Gambar 21. 


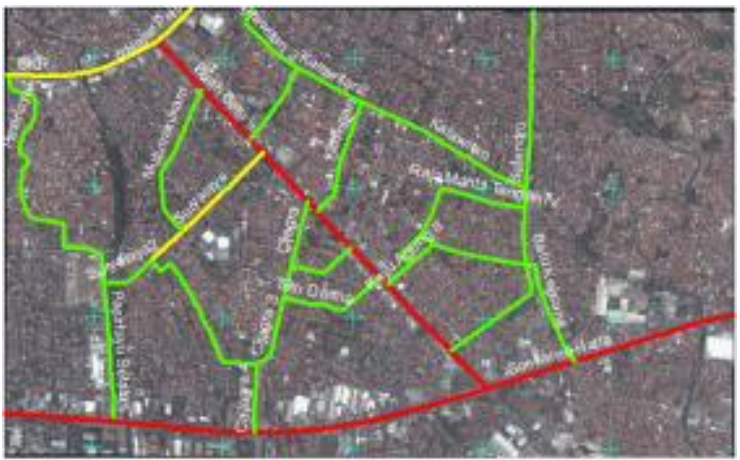

Gambar 21. Pengalihan arus menuju jalan Suryalaya.

e. Pengalihan arus menuju jalan BKR via jalan Cijagra.

Pengalihan yang dilakukan pada simulasi ini dilakukan jika hanya disalurkan menuju jalan Cijagra saja, maka rute yang dapat diambil menuju jalan BKR adalah jalan Buah Batu - Cijagra - Suryalaya Timur -Suryalaya Tengah - Suryalaya - Pasir Luyu. Dengan menerapkan solusi ini maka didapatkan nilai DS untuk solusi ini menjadi 1,30. Adapun yang dimaksud pada solusi ini dapat dilihat pada Gambar 22.

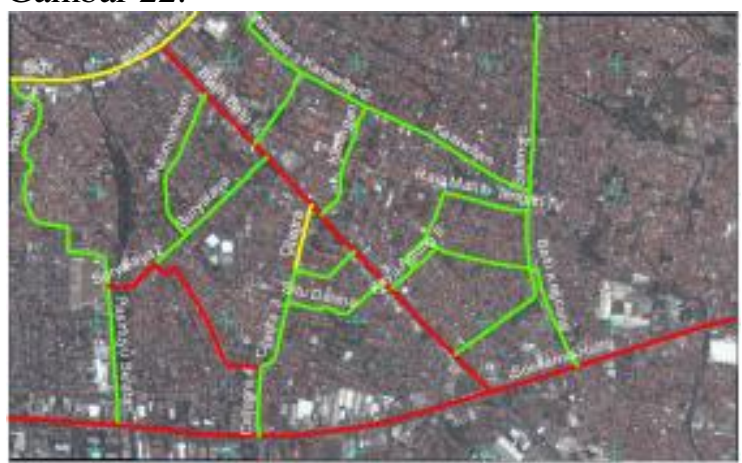

Gambar 22. Pengalihan arus menuju jalan Cijagra.
f. Pengalihan arus menuju jalan BKR via jalan Situ Lembang.

Pada simulasi ini dicoba pengalihan hanya melalui jalan situ lembang saja dengan menggunakan rute jalan Buah Batu - Situ Lembang - Situ Gede - Cijagra - Suryalaya Timur - Suryalaya Tengah - Suryalaya - Pasir Luyu. Dengan menerapkan solusi ini maka didapatkan nilai DS untuk solusi ini menjadi 1,35 . Adapun yang dimaksud pada solusi ini dapat dilihat pada Gambar 23.

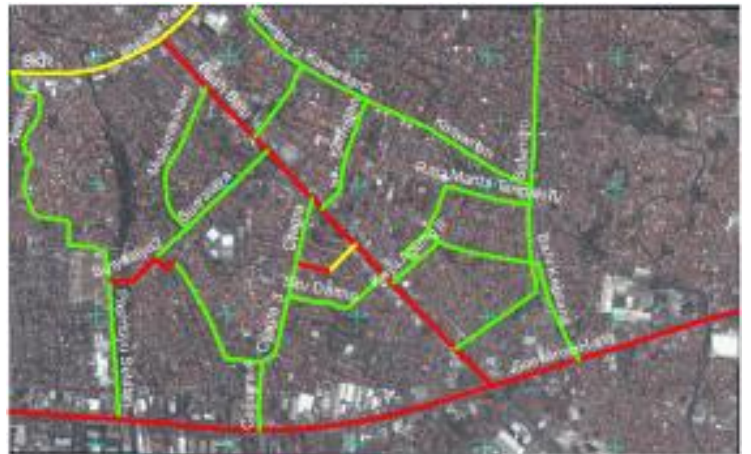

Gambar 23. Pengalihan arus menuju jalan Situ Lembang.

g. Pengalihan arus menuju menuju jalan BKR via jalan Situ Patenggang.

Pada simulasi ini dicoba pengalihan hanya melalui jalan situ lembang saja dengan menggunakan rute jalan buah batu - Situ Patenggang - Situ Batu - Situ Darma - Cijagra - Suryalaya Timur - Suryalaya Tengah Suryalaya - Pasir Luyu. Dengan menerapkan solusi ini maka didapatkan nilai DS untuk solusi ini menjadi 1,35 . Adapun yang dimaksud pada solusi ini dapat dilihat pada Gambar 24.

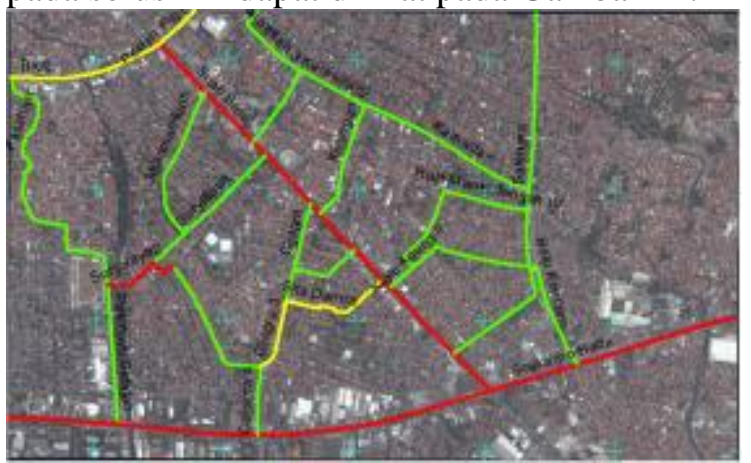

Gambar 24. Pengalihan arus menuju jalan Situ Patenggang.

h. Kombinasi pengalihan secara serentak menuju menuju jalan BKR via jalan Suryalaya, Cijagra, Situ Lembang dan Situ Patenggang.

Pada simulasi yang dilakukan dengan mengalihkan arus secara serentak ini memang menghasilkan nilai DS tidak jauh berbeda dibandingkan solusi sebelumnya yaitu $=1,21$ kepadatan juga terjadi pada ruas alternatif, karena bukan hanya dikarenakan arus kendaraan yang masuk diasumsikan sesuai dengan kapasitasnya tetapi karena serentaknya kendaraan masuk, disisi lain juga jalan alternative ini juga cukup terintegrasi antara satu dengan yang lainnya sehingga dampaknya juga dapat beruntun. Dengan menerapkan solusi ini maka didapatkan nilai DS untuk 
solusi ini menjadi 1,21. Adapun yang dimaksud pada solusi ini dapat dilihat pada Gambar 25.

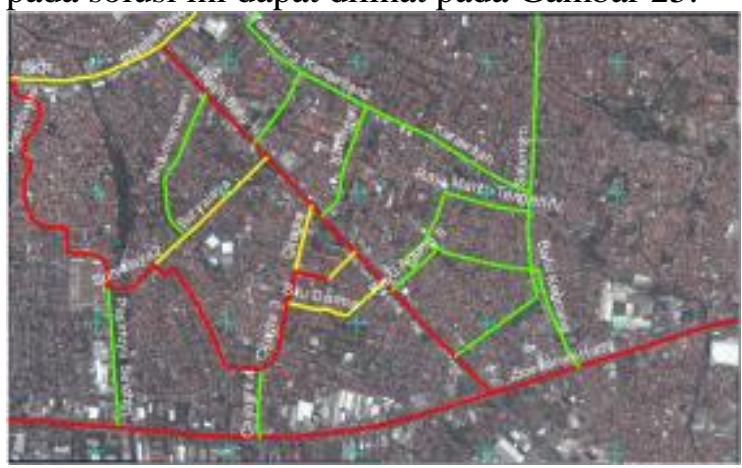

Gambar 25. Pengalihan arus kombinasi (arah jalan BKR).

i. Pengalihan arus menuju jalan Pelajar Pejuang 45 via jalan Guntur Sari Wetan.

Pada simulasi ini dicoba pengalihan hanya melalui jalan situ lembang saja dengan menggunakan rute jalan buah batu - Situ Patenggang - Situ Batu - Situ Darma - Cijagra - Suryalaya Timur - Suryalaya Tengah Suryalaya - Pasir Luyu. Dengan menerapkan solusi ini maka didapatkan nilai DS untuk solusi ini menjadi 1,33 . Adapun yang dimaksud pada solusi ini dapat dilihat pada Gambar 26.

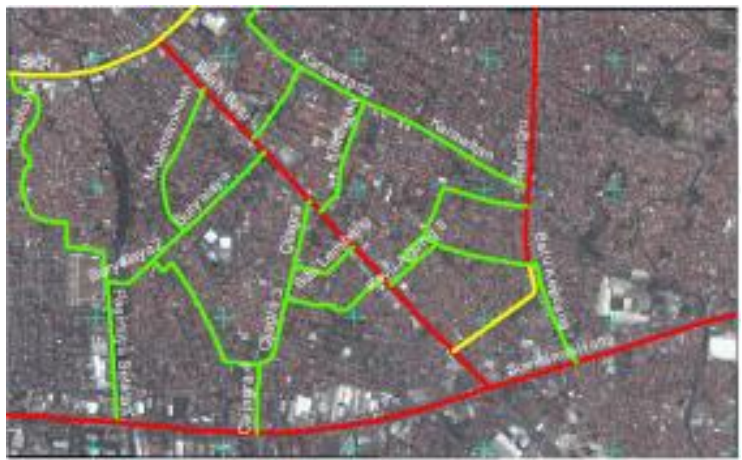

Gambar 26. Pengalihan arus menuju jalan Guntur Sari Wetan.

j. Pengalihan arus menuju jalan Pelajar Pejuang 45 via jalan Kayu Agung II.

Pengalihan arus ini dilakukan untuk membagi arus jalan buah batu yang akan menuju jalan Pelajar Pejuang 45, dalam hal ini rute yang di ajukan adalah jalan Buah Batu Guntur Sari Wetan - Raja Mantri Tengah IV Turangga - Gatot Subroto - Pelajar Pejuang 45. Dengan menerapkan solusi ini maka didapatkan nilai DS untuk solusi ini menjadi 1,35. Adapun yang dimaksud pada solusi ini dapat dilihat pada Gambar 27.

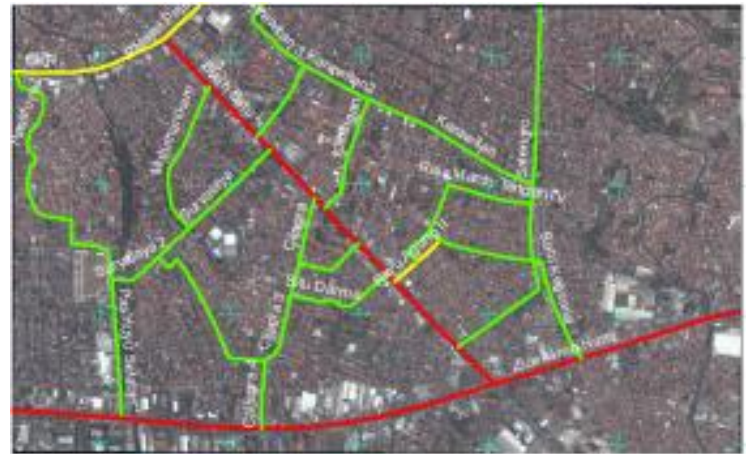

Gambar 27. Pengalihan arus menuju jalan Kayu Agung II.

k. Pengalihan arus menuju jalan Pelajar Pejuang 45 via jalan Kliningan.

Pada pengalihan arus yang digunakan ini maka akan didapatkan rute baru yaitu jalan Buah Batu - Kliningan - Karawitan Maskumambang - Martanegara - Pelajar Pejuang 45. Dengan menerapkan solusi ini maka didapatkan nilai DS untuk solusi ini menjadi 1,33. Adapun yang dimaksud pada solusi ini dapat dilihat pada Gambar 28.

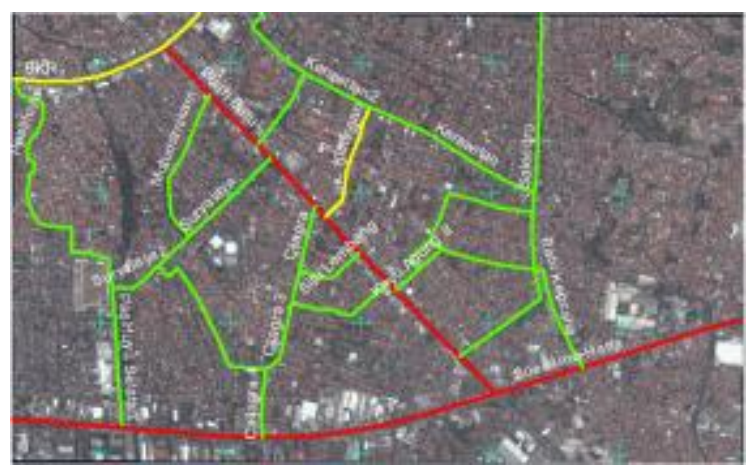

Gambar 28. Pengalihan arus menuju jalan Kliningan.

1. Pengalihan arus menuju jalan Pelajar Pejuang 45 via jalan Solontongan.

Pada pengalihan arus ini rute yang akan digunakan adalah jalan Buah BatuSolontongan - Guntur madu - Kenanti Martanegara - Pelajar pejuang 45. Dengan menerapkan solusi ini maka didapatkan nilai DS untuk solusi ini menjadi 1,34. Adapun yang dimaksud pada solusi ini dapat dilihat pada Gambar 29. 


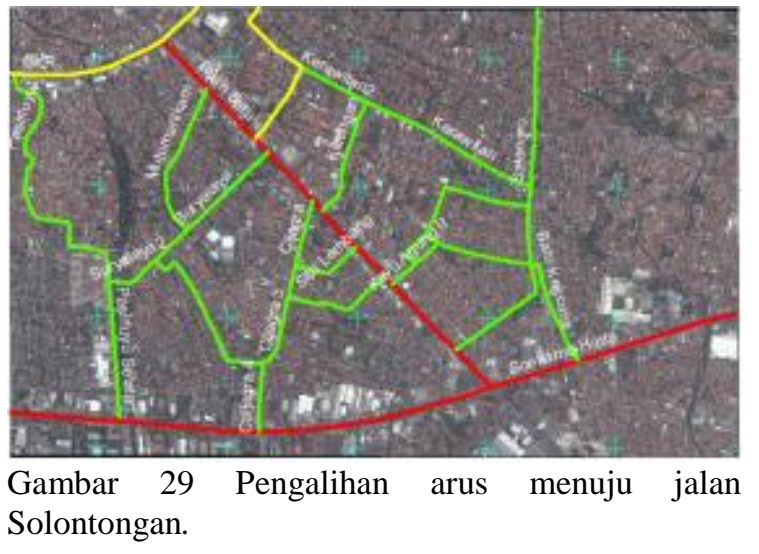

m. Pengalihan arus menuju jalan Pelajar Pejuang 45 secara serentak via jalan Guntur Sari Wetan, Kayu Agung II, Kliningan dan Solontongan.

Pada simulasi ini pengalihan arus yang dilakukan langsung pada ke empat ruas jalan sebelumnya, yaitu Guntur Sari Wetan, Kayu Agung II, Kliningan dan solontongan. Dengan menerapkan solusi ini maka didapatkan nilai DS untuk solusi ini menjadi 1,26. Adapun yang dimaksud pada solusi ini dapat dilihat pada Gambar 30.

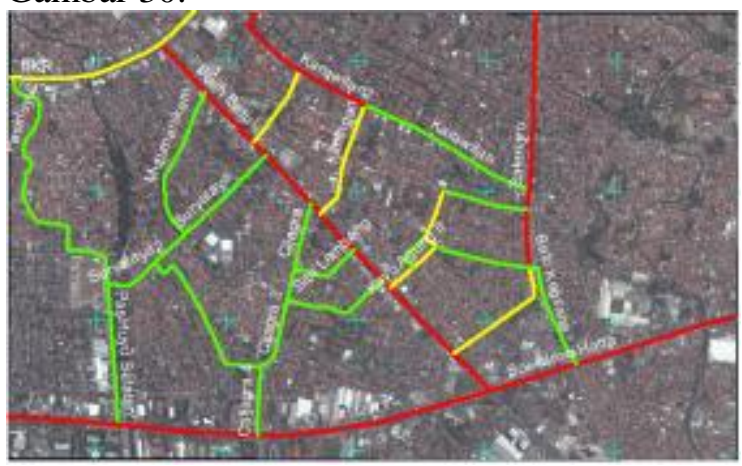

Gambar 30.. Pengalihan Arus Kombinasi (arah jalan Pelajar Pejuang 45).

\section{V.Kesimpulan}

Dari hasil perancangan struktur atas jembatan yang telah dilakukan, maka dapat diambil beberapa kesimpulan sebagai berikut:

1. Analisis kapasitas jalan menggunakan pendekatan geospasial dapat digunakan dengan memperhatikan bangkitan dan tarikan disekitar lokasi tinjauan yang dapat dilihat dari tata guna lahannya, selain itu dapat dilihat juga ruas jalan terdekat yang terhubung dengan ruas jalan yang menjadi lokasi tinjauan.

2. Nilai derajat kejenuhan jalan Ahmad Yani.
a. $2015=0,99$
b. $2020=1,35$

3. Nilai derajat kejenuhan jalan Ahmad Yani pasca penerapan solusi.
a. Solusi $1=1,21$
b. Solusi $2=1,07$
c. Solusi $3=1,19$
d. Solusi $4=1,07$
e. Solusi $5=0,76$

4. Nilai derajat kejenuhan jalan Buah Batu.
a. $2015=0,99$
b. $2020=1,36$

5. Nilai derajat kejenuhan jalan Ahmad Yani pasca penerapan solusi.
a. Solusi $1=1,07$
b. Solusi $2=1,12$
c. Solusi $3=1,21$
d. Solusi $4=1,30$
e. Solusi $5=1,30$
f. Solusi $1=1,35$
g. Solusi $2=1,35$
h. Solusi $3=1,21$
i. Solusi $4=1,33$
j. $\quad$ Solusi $5=1,35$
k. Solusi $4=1,33$
1. Solusi $5=1,34$
m. Solusi $5=1,26$

6. Mayoritas jalan di kota Bandung, khususnya Bandung Tengah sudah mulai mengalami kepadatan lalu lintas, hal ini dapat dilihat dari nilai VCRnya yang sudah banyak menginjak angka $>0,75$.

\section{Daftar Pustaka}

1997. Manual Kapasitas Jalan Indonesia. Direktorat Jendral Bina Marga Bina Jalan Kota. Jakarta

,2004. Survai Pencacahan Lalu Lintas dengan Cara Manual. Departemen Pemukiman dan Prasarana Wilayah. Jakarta

,2011. Undang-Undang No. 4 Tahun 2011 tentang Informasi Geospasial. Jakarta

2012. Survei Lalu Lintas Kota Bandung. Dinas Perhubungan. Bandung

R.B.P Desutama R. (2010) Buku I Bahan Ajar Manajemen Lalu Lintas. Jurusan Teknik Sipil Politeknik Negeri Bandung

Nurdyawati I.S. 2013. Laporan Praktikum ERMapper Pengolahan Data Citra. Fakultas Teknik Universitas Diponegoro. Semarang

Tamin Ofyar.Z, 2000. Perencanan dan pemodelan transportasi edisi kedua. Bandung: Penerbit ITB. 